\title{
Biochar uygulamalarının ekmeklik buğdayın kadmiyum (Cd) alımına etkisi*
}

\author{
Yasemin ACIR ${ }^{(1)}$, Halil ERDEM ${ }^{2} 2$ \\ ${ }^{1}$ Kırşehir Ahi-Evran Üniversitesi Üniversitesi, Teknik Bilimler Meslek Yüksekokulu, Bitkisel ve Hayvansal Üretim Bölümü, Kırşehir. \\ ${ }^{2}$ Tokat Gaziosmanpaşa Üniversitesi, Ziraat Fakültesi, Toprak Bilimi ve Bitki Besleme Bölümü, Tokat
}

*Bu çalışma, birinci yazarın ikinci yazar danışmanlığında hazırladığı yüksek lisans tezinden üretilmiştir.

Alınış tarihi: 20 Ekim 2020, Kabul tarihi: 5 Aralık 2020

Sorumlu yazar: Halil ERDEM, e-posta: erdemh@hotmail.com

\section{Öz}

Günümüzde çevresel felaketlerin başında yer alan küresel ısınma ve son zamanlarda adından çokça bahsedilen ağır metal kirliliği, insanoğlunun yaşam standartlarını sinırlandırmaktadır. Ağır metallerden kadmiyum (Cd), topraklarda yüksek konsantrasyonlarda bulunduğunda hem bitki büyümesine hem de bu bitkilerle beslenen canlılara zarar vermektedir. Bu çalışmanın amacı, yüksek Cd konsantrasyonuna sahip topraklarda organik madde miktarını artırarak Cd hareketliliğini ve bitkiye $\mathrm{Cd}$ tașınmasını azaltmaktır. Organik materyal olarak, özellikle son zamanlarda küresel ısınmanın etkisini azaltabilmek için kullanılan organik materyalin piroliz edilmesi ile elde edilen biochar seçilmiştir. $\mathrm{Bu}$ çalıșmada, biochar materyali olarak mahlep çekirdeği kullanılmış ve biochar materyali biyokütlenin yavaş piroliz işlemi ile elde edilmiştir. Deneme sera koşullarında yürütülmüş ve Ceyhan-99 ekmeklik buğday çeşidi kullanılmıştır. Denemede 5 farklı Cd dozu (0, 2.5, 5, 10 ve $\left.20 \mathrm{mg} \mathrm{kg}^{-1}\right)$ ve 6 farklı biochar dozu $(\% 0,0.5,1,2,3$ ve 4$)$ uygulanmıştır. Hasat edilen bitkilerin yeşil aksam kuru madde verimi ile $C d$, azot $(\mathrm{N})$, fosfor $(\mathrm{P})$, potasyum $(\mathrm{K})$, çinko (Zn) ve demir (Fe) konsantrasyonları belirlenmiştir. Elde edilen sonuçlara göre toprağa artan düzeyde biochar ve Cd uygulanması ile kuru madde verimi kontrol uygulamalarına göre istatistiksel olarak azalmıştır. Buna ek olarak, elde edilen başka önemli bir sonuç ise, Cd'un $10 \mathrm{mg} \mathrm{kg}^{-1}$ ve $20 \mathrm{mg} \mathrm{kg}^{-1}$ dozunda \%4 oranında uygulanan biochar materyalinin Cd'un bitkideki konsantrasyonunu kontrol uygulamasına göre sırasıyla \% 40,49 ve \% 35,76 oranında azaltmasıdır.
Çalışmada elde edilen veriler, $\mathrm{Cd}$ ile kirlenmiş topraklara biochar uygulanması ile bitkilerin $\mathrm{Cd}$ alımının azaltılabileceğini göstermiștir.

Anahtar kelimeler: Ağır metal, kadmiyum, biochar, kuru madde, konsantrasyon

\section{Effect of biochar applications on cadmium (Cd) uptake of bread wheat}

\section{Abstract}

Global warming, nowadays that is leading the environmental disaster and heavy metal pollution which has been discussed a lot, recently constrains the living standards of mankind. High cadmium (Cd), one of the heavy metals exerts harmful to both plant growth and to the living organisms fed by the plants. The purpose of this study is to reduce the mobility and transport of $\mathrm{Cd}$ to plants in soils of high cadmium concentration through increasing the amount of organic matter. Biochar recently produced by the thermochemical pyrolysis of organic material particularly to reduce the effects of global warming was selected as an organic material. In this study, mahaleb seeds were used as biochar material, biochar material was obtained by heating biomass in the absence of oxygen called slow pyrolysis process. Ceyhan-99 bread wheat varieties were used in greenhouse experiment. Five different cadmium doses $\left(0,2.5,5,10\right.$ and $\left.20 \mathrm{mg} \mathrm{kg}^{-1}\right)$ and 6 biochar rates $(0 \%, 0.5,1,2,3$ and 4$)$ were applied to soil with 3 replications. Cd, nitrogen $(\mathrm{N})$, phosphorus $(\mathrm{P})$, potassium $(\mathrm{K})$, iron $(\mathrm{Fe})$ and zinc $(\mathrm{Zn})$ concentrations were determined in the green parts of plants harvested. According to the results
\end{abstract}


obtained, dry matter yield decreased statistically with the application of increasing biochar and $\mathrm{Cd}$ to the soil compared to the control applications. In addition, another important result obtained that the biochar material applied at a rate of $4 \%$ for $\mathrm{Cd} 10$ and $20 \mathrm{mg} \mathrm{kg}^{-1}$ doses reduced $\mathrm{Cd}$ concentration in plant $40.49 \%$ and $35.76 \%$, respectively, as compared to the control. The results revealed that biochar application might reduce the Cd uptake of plants in soils contaminated with $\mathrm{Cd}$.

Key words: Heavy metal, cadmium, biochar, dry matter, concentration

\section{Giriş}

Yaşadığımız ekosistemde ağır metal kirliliği çeşitli nedenlerden dolayı olmaktadır (Goyer ve ark., 1989). Ağır metallerin çevreye yayılmasına neden olan etmenlerden bir tanesi de tarımda gübre ve pestisitlerin yoğun olarak kullanılmasıdır (Asri ve Sönmez, 2006). Toprakta bulunan ağır metaller içerisinde $\mathrm{Zn}, \mathrm{Mn}, \mathrm{Co}, \mathrm{Cu}$, Ni ve Mo bitki gelişimi için mutlak gerekli iken $\mathrm{Al}, \mathrm{V}, \mathrm{Ar}, \mathrm{Hg}, \mathrm{Pb}$, Se ve Cd toksik etkiye sahiptir. Gür ve ark. (2004), mutlak gerekli olsun veya olmasın ağır metallerin doku ve organlardaki aşırı birikiminin bitkilerin vejetatif ve genaratif organlarında gelişimi olumsuz etkilediğini rapor etmişlerdir. Haktanır (1987), ağır metaller içerisinde yer alan Cd'un, tarım arazilerine girişi ve yayılmasının sebebinin endüstriyel faaliyetler, fosforlu gübreler, kanalizasyon atıkları ve atmosferik depozitler olduğunu rapor etmiștir. Kadmiyumun toprakta hareketli bir element olup bitkiler tarafından kolaylıkla alınabilmektedir. Kadmiyum bitki bünyesinde azot ve karbonhidrat metabolizmalarının aktivitesini değiștirerek bitkide birçok fizyolojik değişikliğe neden olmaktadır (Asri ve Sönmez, 2007) ve proteinlerdeki enzimleri etkisiz hale getirerek, fotosentezi engellemekte, stomaların kapanmasına, terleme ile su kaybının azalmasına ve klorofil biyosentezinin bozulmasina neden olmaktadır (Sheoran ve ark., 1990). İnsanlar üzerinde $\mathrm{Cd}$ akciğer, karaciğer ve böbrek rahatsızlıklarına, görme bozukluğuna, kansızlık ve yüksek tansiyona neden olmaktadır (Jarup ve ark., 1998). Dokularında $3 \mathrm{mg} \mathrm{kg-1'den} \mathrm{daha} \mathrm{fazla} \mathrm{Cd}$ içeren bitkileri düzenli olarak tüketen insanlarda $\mathrm{Cd}$ toksitesinin neden olduğu sağlı problemleri görülmektedir (Alloway, 1995). İnsan ve hayvan sağlığına olumsuz etki yapmayan kaliteli ve verimli ürünler elde edebilmek için, ağır metal kirliliğine maruz kalmış alanlardan, bu kirleticilerin uzaklaştırılması gerekmektedir. Ancak bu uygulamalar genelde ekonomik değildir. Birçok durumda topraklar, ağır metaller için son depolanma yeri olabilmektedir. Bu olayda toprakların doğal filtre edici özellikleri ile tamponlanma kapasiteleri büyük önem taşımaktadır. Toprakta yeterli düzeyde negatif yük yoksa toprak çözeltisinde serbest halde bulunan ağır metaller toprakta yaşayan canlılar (mikroorganizmalar vb.) ve bitki kökleri tarafından alınmakta ya da toprakta yıkanarak yer altı suyuna karışmaktadır. Yer altı sularında ağır metal birikimi meydana gelmiş sularla sulanan bitkiler, bu bitkilerle beslenen hayvanlar ve insanların sağlığı üzerine de önemli olumsuz etkileri söz konusudur (Ylldız, 2001). Son yillarda küresel ısınma ile mücadele amaçlı da kullanılan biochar, toprağa ilave edildiğinde toprağın fiziksel, kimyasal ve biyolojik özelliklerini de iyileştirmektedir. Biochar, toprak özelliklerine bağlı olmakla beraber su ve besin elementi tutumu veya mikrobiyal aktivite gibi özelliklere direk etki etmektedir (Lehmann ve ark., 2011). Biochar negatif yüklü ve oldukça yüksek iyon değişimine (Pena ve ark., 2000; Zhang ve ark., 2009), büyük gözenekliliğe (Chen ve ark., 2011), ve yüksek adsorbsiyon yeteneğine (Washington ve ark., 2003; Kramer ve ark., 2004) sahiptir. Biochar bu üstün özellikleri sayesinde farklı disiplinlerden bilim insanlarının ilgisini çekmiş ve çekmeyede devam etmektedir. Biochar, özellikle insanlarm neden olduğu, henüz tehlikeli boyutlara ulaşmamış ağır metal kirlenmesinin, gelecekte tüm canlılara büyük bir sorun teşkil etmeden önlenmesi konusunda önemli rol oynayacağı düşünülmektedir. $\mathrm{Bu}$ çalışmada, yüksek $\mathrm{Cd}$ konsantrasyonuna sahip topraklarda organik madde miktarını artırarak $\mathrm{Cd}$ hareketliliğini ve bitkiye Cd taşınmasını azaltmak amacıyla biochar uygulamalarının ekmeklik buğdayın Cd alımına etkisini belirlemektedir.

\section{Materyal ve Yöntem \\ Materyal}

Sera koşullarında gerçekleştirilen denemede Ceyhan-99 ekmeklik buğday çeşidi kullanılmıştır. Denemede kil tekstüre sahip, kireçli (\%26.2), alkali karekterde (pH:7.93), tuzsuz (0.44 dS/m), DTPA'da ekstrakte edilebilir Cd konsantrasyonu $0.005 \mathrm{mg} \mathrm{kg}^{-1}$ olan bir toprak kullanılmıştır. Denemede kullanılan biochar materyali mahlep çekirdeğinden elde edilmiştir. Mahlep çekirdeğinden biochar üretimi, biyokütlenin oksijensiz ortamda ssıtılması adı verilen yavaş piroliz işlemi ile elde edilmiştir. Araştırmada kullanılan mahlep çekirdeğinden üretilen biocharın 
C/N oranı 172/1, $\mathrm{pH}^{\prime}$ sl 5.17, toplam $\mathrm{P}$ konsantrasyonu $\% 0.06$, K konsantrasyonu $\% 0.17$ ve Cd konsantrasyonu ise $0.09 \mathrm{mg} \mathrm{kg}^{-1}$ 'dır.

\section{Yöntem}

Araştırma 3 tekerrürlü olarak kurulmuş, denemede plastik saksı kullanılmış ve her saksıya $1750 \mathrm{~g}$ toprak tartılmıştır. Tüm saksılara $250 \mathrm{mg} \mathrm{kg}^{-1} \mathrm{~N}$, $\mathrm{Ca}\left(\mathrm{NO}_{3}\right)$ formunda, $100 \mathrm{mg} \mathrm{kg}^{-1} \mathrm{P}, 125 \mathrm{mg} \mathrm{kg}^{-1} \mathrm{~K}$, $\mathrm{KH}_{2} \mathrm{PO}_{4}$ formunda, $2 \mathrm{mg} \mathrm{kg}^{-1} \mathrm{Fe}$, Fe-EDTA formunda ve $2 \mathrm{mg} \mathrm{kg}^{-1} \mathrm{Zn}, \mathrm{ZnSO}_{4}$ formunda temel gübreleme yapılmıştır. Denemeye konu olan Cd; 0 (Cdo), 2.5 $\left(\mathrm{Cd}_{2.5}\right), 5\left(\mathrm{Cd}_{5}\right), 10\left(\mathrm{Cd}_{10}\right)$ ve $20\left(\mathrm{Cd}_{20}\right) \mathrm{mg} \mathrm{kg}^{-1}$ dozları şeklinde ve $3 \mathrm{CdSO}_{4} .8 \mathrm{H}_{2} \mathrm{O}$ formunda uygulanmıştır. Biochar dozları ise yüzde olarak sırası ile $\% 0, \% 0.5$, $\% 1.0, \% 2.0, \% 3.0$ ve $\% 4.0$ olacak şekilde denemenin kurulması sırasında diğer gübreler ile birlikte homojen bir şekilde toprakla karıștırılarak uygulanmıștır. Saksı bașına 10 tohum ekilmiş ve çimlenmeden sonra bu sayı 6'ya seyreltilmiştir. Bitkiler günlük olarak su ihtiyaçlarına göre saf su ile sulanmıştır. Bitkiler, Cd simptomlarının şiddetine ve yeşil aksamda meydana gelen büyüme gerilemesine bağlı olarak 53. günde hasat edilmiştir. Hasat edilen bitkiler yıkanıp 48 saat boyunca $70^{\circ} \mathrm{C}$ ' ye ayarlanmış etüvde kurutulup, kuru ağırlıkları belirlenmiștir. Kuru ağırlıkları belirlenen örnekler daha sonra Agat değirmeninde öğütülerek analize hazır duruma getirilmiştir. Öğüülen bitki örnekleri mikrodalga cihazında (Mars Xpress) yaş yakma metoduna göre $\mathrm{H}_{2} \mathrm{O}_{2}-\mathrm{HNO}_{3}$ asit karışımında yakılmış, yakılan numunelerde $\mathrm{Cd}, \mathrm{P}, \mathrm{K}, \mathrm{Zn}$ ve $\mathrm{Fe}$ elementlerinin konsantrasyonları ICP-OES cihazında (Perkin Elmer, 2100 DV Optima) belirlenmiștir. (Kaçar ve İnal, 2008). Yeşil aksam örneklerinde $\mathrm{N}$ analizi ise Kjeldahl destilasyon yöntemine göre yapılmıştır (Bremner, 1965).

\section{İstatistiksel Analizler}

Uygulanan her bir Cd dozunda (0, 2.5, 5, 10 ve 20.0 mg kg-1) yeşil aksam kuru madde verimi ve besin elementi konsantrasyonları üzerine biochar dozlarının ( $\% 0, \% 0.5, \% 1, \% 2, \% 3$ ve $\% 4)$ etkilerinin istatistiksel olarak anlamlı olup olmadığı tek yönlü varyans analizi (ANOVA) testi uygulanarak belirlenmiştir. Biochar uygulamalarının yeşil aksam kuru madde ve besin elementi konsantrasyonları açısından benzer olanlarının gruplandırılmalarında ise DUNCAN homojenlik testi kullanılmıştır. İstatistiksel analizlerde SPSS 21.0 paket programı kullanılmıştır.

\section{Araştırma Bulguları ve Tartışma}

Artan dozlarda biochar ve Cd uygulamasının ekmeklik buğdayın yeşil aksam kuru madde verimi üzerine etkisi

Biochar uygulamalarında ekmeklik buğday bitkisinin yeşil aksam kuru madde içeriği, Cd uygulamasının yapılmadığı saksı denemelerinde istatistiksel olarak önemli düzeyde çıkmasına rağmen diğer tüm $\mathrm{Cd}$ dozu uygulamalarında önemsiz çıkmıştır (Çizelge 1). Kadmiyum uygulamasının yapılmadığı saksılarda yeşil aksam kuru madde verimi kontrol uygulamasında $2.77 \mathrm{~g}$ bitki $^{-1}$ iken \%4 biochar dozunda $2.04 \mathrm{~g}$ bitki ${ }^{-1}$ düzeyine gerilemiștir. Toprakta biochar materyalinin yüzdelik olarak oranının artması ile yeşil aksam kuru madde miktarındaki azalışın temel nedeni, biochar materyalinin $\mathrm{pH}$ içeriğinin çok düşük olmasından kaynaklandığı düşünülmektedir. Rengel (2003) toprakta asitlik şartlarının artması ile kuru madde miktarının azaldığını bildirmektedir. Bunun en temel nedeninin de değişim komplekslerinde daha fazla miktarda bulunan $\mathrm{H}^{+}$iyonunun, diğer makro ve mikro besin elementleri ile rekabete girerek makro ve mikro besin elementlerinin bitkiye taşınım konsantrasyonlarını azaltmasından kaynaklandığını bildirmiştir. Bunun yanı sıra özellikle düşük pH’larda P'un fiksasyonu ve $\mathrm{Al}^{+3}$ iyonunun artması kuru madde miktarının azalmasına neden olabilir.

Çizelge 1. Farklı Cd ve Biochar dozları uygulanarak yetiştirilen ekmeklik buğdayın yeşil aksam kuru madde verimi

\begin{tabular}{|c|c|c|c|c|c|c|}
\hline \multirow{2}{*}{ Biochar Dozu (\%) } & $\mathrm{Cd} 0$ & $\mathrm{Cd} 2.5$ & Cd5.0 & Cd10 & $\mathrm{Cd} 20$ & Ortalama \\
\hline & \multicolumn{6}{|c|}{ Yeșil aksam kuru madde verimi (g bitki-1) } \\
\hline 0 & $2.77^{a}$ & 2.35 & 2.10 & 1.92 & 2.08 & 2.24 \\
\hline 0,5 & $2.57^{a b}$ & 2.18 & 2.19 & 2.10 & 1.91 & 2.19 \\
\hline 1 & $2.22^{\mathrm{bc}}$ & 1.92 & 2.23 & 2.03 & 1.93 & 2.07 \\
\hline 2 & $2.41^{\mathrm{abc}}$ & 2.17 & 2.10 & 2.14 & 1.95 & 2.15 \\
\hline 3 & $2.37^{\mathrm{abc}}$ & 1.96 & 2.14 & 2.12 & 1.97 & 2.11 \\
\hline 4 & $2.04^{c}$ & 1.93 & 1.99 & 2.07 & 2.09 & 2.02 \\
\hline Ortalama & $2.40^{\mathrm{A}}$ & $2.09^{B}$ & $2.13^{\mathrm{B}}$ & $2.06^{\mathrm{B}}$ & $1.99^{\mathrm{B}}$ & \\
\hline
\end{tabular}

*Sütunlarda aynı harfle gösterilen değerler arasında istatistiksel olarak $\mathrm{P}<0,05$ düzeyinde farklılık yoktur. 
Çizelge 1'de biochar uygulamasının yapılmadığı saksılarda, artan Cd dozu ile birlikte bitkinin yeşil aksam kuru madde verimi bütün $\mathrm{Cd}$ uygulamalarında kontrol uygulamasına göre azalmıştır. $\mathrm{Cd}_{0}$ dozunda $2.77 \mathrm{~g}^{\text {bitki }}{ }^{-1}$ olan ortalama verim $\mathrm{Cd}_{20}$ dozunda 2.08 'e düşmüştür. Khurana ve Jhanji (2014), mısır bitkisine artan düzeyde Cd uygulaması ile yeşil aksam kuru madde miktarının önemli düzeyde azaldığını bildirmișlerdir. Araştırıcılar yaptıkları çalışmada $10 \mathrm{mg} \mathrm{kg}^{-1} \mathrm{Cd}$ uygulamasında verimin \%11.9, Cd'un $20 \mathrm{mg} \mathrm{kg}^{-1}$ uygulamasında ise \% 23.5 düzeyinde verimde bir azalmanın olduğunu bildirmişlerdir. Kuru madde veriminde meydana gelen bu azalmanin temel nedeninin Cd'un fitotoksik etkisinden kaynaklandığı düşünülmektedir (Gussarson ve ark., 1996; Yang ve ark., 1996; Pereira ve ark., 2011). Kalınbacak ve ark. (2012), tarafından yürütülen bir başka çalışmada sera koşullarında toprağa $0,5,15,30$ ve $45 \mathrm{mg} \mathrm{kg}^{-1}$ $\mathrm{Cd}$ uygulanmış ve buğday bitkisinin kuru madde miktarının Cd dozlarının artması ile azaldığı rapor edilmiştir.

\section{Artan dozlarda biochar ve Cd uygulamalarının ekmeklik buğdayın yeşil aksam Cd konsantrasyonları üzerine etkisi}

Kadmiyumun 2.5 dozunda ve artan biochar uygulamaları altında bitkilerin yeşil aksam $\mathrm{Cd}$ konsantrasyonu $2.66 \mathrm{mg} \mathrm{kg}^{-1}$ ile $3.62 \mathrm{mg} \mathrm{kg}$ ${ }^{1}$ arasında değişkenlik göstermiştir (Çizelge 2). Kadmiyum konsantrasyonu kontrol uygulamasina göre \%3 biochar dozunda \%26,01 oranında artış gösterse de bu değişkenlik istatistiksel olarak önemli bulunmamıştır. Toprağa yapılan $5 \mathrm{mg} \mathrm{kg-1} \mathrm{Cd}$ uygulaması ile farklı dozlarda biochar uygulaması altında yetiştirilen bitkilerin yeșil aksam Cd konsantrasyonunda sadece biocharın \% 0.5 dozunda bir azalıș olmuş, buna karşın Cd $10 \mathrm{mg} \mathrm{kg}^{-1}$ ve artan dozlarda biochar uygulaması koşullarında bitkilerin yeşil aksam Cd konsantrasyonu 11.42 mg kg-1'dan (kontrol) ile $6.97 \mathrm{mg} \mathrm{kg}^{-1}$ 'a (\%4 biochar) düştüğü bulunmuştur (Çizelge 2).

Çizelge 2. Farklı Cd ve Biochar dozları uygulanarak yetiştirilen ekmeklik buğdayın yeşil aksam Cd konsantrasyonları $\left(\mathrm{mg} \mathrm{kg}^{-1}\right)$

\begin{tabular}{|c|c|c|c|c|c|c|}
\hline \multirow{2}{*}{ Biochar Dozu \% } & $\mathrm{Cd} 0$ & $\mathrm{Cd} 2.5$ & Cd5.0 & $\mathrm{Cd} 10$ & $\mathrm{Cd} 20$ & Ortalama \\
\hline & \multicolumn{6}{|c|}{ Yeşil aksam Cd konsantrasyonu (mg kg-1) } \\
\hline 0 & 0.08 & 2.89 & $4.63^{\mathrm{b}}$ & $11.42^{\mathrm{c}}$ & $19.99^{a}$ & $7.80^{\mathrm{D}}$ \\
\hline 0,5 & 0.06 & 2.70 & $3.17^{\mathrm{a}}$ & $11.38^{\mathrm{c}}$ & $14.75^{\mathrm{ab}}$ & $6.41^{\mathrm{B}}$ \\
\hline 1 & 0.08 & 2.90 & $6.20^{c}$ & $9.65^{\mathrm{bc}}$ & $18.10^{\mathrm{ab}}$ & $7.39^{\mathrm{C}}$ \\
\hline 2 & 0.08 & 2.98 & $5.87 \mathrm{c}$ & $7.54^{\mathrm{ab}}$ & $15.64^{\mathrm{ab}}$ & $6.42^{\mathrm{B}}$ \\
\hline 3 & 0.03 & 3.62 & $5.57^{b c}$ & $7.58^{\mathrm{ab}}$ & $13.71^{\mathrm{b}}$ & $6.10^{\mathrm{B}}$ \\
\hline 4 & 0.08 & 2.66 & $6.03^{\mathrm{c}}$ & $6.97 \mathrm{a}$ & $12.82^{\mathrm{b}}$ & $5.71^{\mathrm{A}}$ \\
\hline Ortalama & $0.07^{\mathrm{A}}$ & $2.96^{\mathrm{B}}$ & $5.25^{\mathrm{C}}$ & $9.09^{\mathrm{D}}$ & $15.84^{\mathrm{E}}$ & \\
\hline
\end{tabular}

*Sütunlarda aynı harfle gösterilen değerler arasında istatistiksel olarak $\mathrm{P}<0,05$ düzeyinde farklılık yoktur.

Biochar uygulamaları arasında istatistiksel olarak farkın olduğu Cd konsantrasyonlarında DUNCAN testi sonuçlarına göre $\% 4$ biochar dozu tüm uygulamalardan farklı çıkarak ayrı grupta yer almıştır. Sonuçlardan da görüldüğü üzere toprağa artan düzeyde biochar ilave edildiğinde bitkinin yeşil aksamında Cd konsantrasyonunda bir azalış meydana gelmiştir. Bunun en temel nedeni toprağın biochar uygulamalarına bağlı olarak negatif yük miktarının artmasına bağlı olarak Cd'un hareketliliğinin azalmasından kaynaklandığı düşünülmektedir. Namgay ve ark. (2010), üç farklı biochar ve Cd dozunda kumlu toprakta yetiştirdikleri mısır bitkisinin Cd içeriğini belirlemişlerdir. Elde ettikleri sonuçlara göre biochar uygulama dozlarının artmasıyla Cd içeriğinin azaldığını ve bunun nedenini ise biochar materyalinin eklenmesiyle yüzey alanının artmasına bağlı olarak iz elementlerin organik materyallere daha sıkı tutulmasına ve daha kararlı metal-organik bileşiklerin oluşmasına dayandırmışlardır. $20 \mathrm{mg} \mathrm{kg}^{-1} \mathrm{Cd}$ uygulaması yapılmış olan deneme topraklarına artan düzeyde biochar uygulamaları ile yeşil aksam Cd konsantrasyonu biochar uygulama dozlarına bağlı olarak istatistiksel olarak önemli düzeyde değişkenlik göstermiştir. Biochar uygulamasının yapılmadığı kontrol toprağında yetişen ekmeklik buğday bitkisinin yeşil aksam Cd konsantrasyonu $19.99 \mathrm{mg} \mathrm{kg}^{-1}$ iken, \%4 biochar uygulamasında bu değer $12.82 \mathrm{mg} \mathrm{kg}^{-1}$ 'e kadar gerilemiştir (Çizelge 2). Organik materyal olarak toprağa eklenen biochar yüksek miktarda negatif değişim yüzeyine sahip olduğundan dolayı Cd'un bu değișim komplekslerinde daha fazla bağlanarak bitkiye taşınmasını azaltmıştır. Lu ve ark. (2012) biochar uygulamaları ile topraklarda ağır metallerin 
sabitlenmesini olası birkaç mekanizmaya dayandığını bildirmiştir. $\mathrm{Bu}$ mekanizmalardan birinci olarak; $\mathrm{Ca}, \mathrm{Mg}$ ve diğer biochar ile bağlantılı katyonlarla yer değiștiren ağır metallerin biocharın mineral oksitleri ve kompleks humik materyaller ile iç küre kompleksleşmesine ve çökelmesine, ikinci olarak; mineral oksitler ve serbest hidroksiller ile iç küre kompleksleşmesine ve farklı fonksiyonel gruplar ile ağır metallerin yüzey kompleksleşmesine, son olarak ise; ağır metallerin fiziksel tutunma ve yüzeyde bağlanmasına dayandırılmıștır.

\section{Artan dozlarda biochar ve Cd uygulamalarının ekmeklik buğdayın yeşil aksam $N, P$ ve $K$ konsantrasyonları üzerine etkisi}

Kadmiyumun uygulanmadığı koşullarda, artan dozlarda biochar uygulaması ile ekmeklik buğday bitkisinin yeşil aksam azot (N) konsantrasyonlarında artış meydana gelmiştir (Çizelge 3). Kontrole göre meydana gelen en yüksek artış (\%28.79) biocharın
\%1 dozunda olup en düşük (\%12.03) artış ise biocharın \%3 dozunda görülmüştür (Çizelge 3). Yeşil aksam N konsantrasyonu Major ve ark. (2012) tarafından da belirtildiği üzere toprağa biochar uygulaması ile birlikte bitkiye taşınan $\mathrm{N}$ konsantrasyonunda da artışlar söz konusudur. Kadmiyum $2.5 \mathrm{mg} \mathrm{kg}^{-1}$ dozunda artan biochar uygulamaları altındaki buğday bitkisinin yeşil aksam $\mathrm{N}$ konsantrasyonu \%2.33 (\%2 biochar) ile \%2.66 (kontrol) arasında değişkenlik göstermiş olup, kontrol uygulamasına göre toprağa artan düzeyde biochar ilavesi ile yeșil aksam N konsantrasyonu tüm biochar uygulamalarında azalış göstermiştir. Kadmiyumun $5 \mathrm{mg} \mathrm{kg}{ }^{-1}$ dozunda ise bitkinin yeşil aksam $\mathrm{N}$ konsantrasyonu, kontrol uygulamalarına göre biochar ilavesi yapılan tüm uygulamalarda artış göstermiş ve söz konusu en yüksek artış \%3 biochar dozunda (\%18.26) olmuştur (Çizelge 3).

Çizelge 3. Farklı Cd ve Biochar dozları altında yetiştirilen ekmeklik buğdayın yeşil aksam N konsantrasyonları (\%)

\begin{tabular}{|c|c|c|c|c|c|c|}
\hline \multirow{2}{*}{ Biochar Dozu \% } & $\mathrm{Cd} 0$ & $\mathrm{Cd} 2.5$ & $\mathrm{Cd} 5.0$ & $\mathrm{Cd} 10$ & $\mathrm{Cd} 20$ & Ortalama \\
\hline & \multicolumn{6}{|c|}{ Yeșil aksam N konsantrasyonu (\%) } \\
\hline 0 & $2.18^{a}$ & 2.66 & 2.08 & $2.77^{d}$ & $2.94^{\mathrm{d}}$ & 2.53 \\
\hline 0,5 & $2.48^{\mathrm{ab}}$ & 2.60 & 2.32 & $2.64^{\mathrm{cd}}$ & $2.88^{\mathrm{cd}}$ & 2.58 \\
\hline 1 & $2.81^{\mathrm{b}}$ & 2.50 & 2.34 & $2.58^{\mathrm{cd}}$ & $2.61^{b c}$ & 2.57 \\
\hline 2 & $2.66^{\mathrm{b}}$ & 2.33 & 2.30 & $2.49^{b c}$ & $2.41^{\mathrm{ab}}$ & 2.44 \\
\hline 3 & $2.44^{\mathrm{ab}}$ & 2.34 & 2.46 & $2.27^{a b}$ & $2.17^{a}$ & 2.34 \\
\hline 4 & $2.52^{\mathrm{ab}}$ & 2.44 & 2.36 & $2.20^{\mathrm{a}}$ & $2.15^{\mathrm{a}}$ & 2.33 \\
\hline Ortalama & 2.52 & 2.48 & 2.31 & 2.49 & 2.53 & \\
\hline
\end{tabular}

*Sütunlarda aynı harfle gösterilen değerler arasında istatistiksel olarak $\mathrm{P}<0,05$ düzeyinde farklılık yoktur.

Kadmiyumun $10 \mathrm{mg} \mathrm{kg}^{-1}$ dozu koşullarında artan düzeyde biochar uygulamaları ile bitkinin yeşil aksam N konsantrasyonlarında önemli düzeyde azalışlar meydana gelmiş ve bu azalış kontrol uygulamasına göre yüzdelik olarak \%4.58 (\%0,5 biochar) ile \%20.52 (\%4 biochar) olarak gerçekleşmiştir. Kadmiyumun $10 \mathrm{mg} \mathrm{kg}^{-1}$ dozunda olduğu gibi, Cd'un $20 \mathrm{mg} \mathrm{kg}^{-1}$ dozunda da artan düzeyde biochar uygulaması, yeşil aksam N konsantrasyonlarında istatiksel olarak önemli azalmalara neden olmuș ve en fazla azalma ise biocharın \%4 dozunda (\%26.83 azalma) meydana gelmiștir. Kontrol uygulamasında $\% 2.94$ olan $\mathrm{N}$ konsantrasyonu, \% 2 biochar dozunda \%2.41'e, \%4 biochar dozunda ise \%2.15'e düşmüştür (Çizelge 3). Denemede $\mathrm{N}$ konsantrasyonlarındaki bu azalıș, her ne kadar biocharın artan düzeyine karşılık bitkinin yeşil aksam Cd konsantrasyonunda azalmalar görülse de, 10 ve $20 \mathrm{mg} \mathrm{kg}^{-1} \mathrm{Cd}$ uygulamalarının bitkinin $\mathrm{N}$ metabolizmasında olumsuzluklara neden olduğu düşünülmektedir. Nitekim, Hernandez ve ark. (1996), Cd'un kök bölgesinde nitrat $\left(\mathrm{NO}_{3}{ }^{-}\right)$redüktaz aktivitesini engelleyerek yaklaşık \%70 oranında nitratın absorbsiyonunu azalttığını rapor etmişlerdir. Ayrıca, Van Assche ve Clijsters (1990), Cd toksitesine bağlı olarak proteinlerdeki sülfürhidrid gruplarına metallerin bağlanması sonucunda, makro besin elementlerinin yer değiştirmesine, yapılarının tahrip edilmesine veya aktivitelerinin engellenmesine yol açarak eksikliğe neden olduğunu rapor etmişlerdir.

Toprağa artan oranlarda biochar uygulamaları ile birlikte yeşil aksam fosfor (P) konsantrasyonu Cd'un tüm uygulamalarında artış göstermiştir, ancak bu artıș $\mathrm{Cd}_{2.5}$ ve $\mathrm{Cd}_{20}$ dozunda istatiksel açıdan önemsiz iken Cd'un diğer dozlarında önemli çıkmıştır (Çizelge 4). Örneğin Cd'un $10 \mathrm{mg} \mathrm{kg}^{-1}$ dozundaki artan düzeyde biochar uygulamaları ile buğday bitkisinin yeşil aksam P konsantrasyonu kontrol uygulamalarına oranla tüm biochar dozu 
uygulamalarında artış göstermiş olup, en yüksek artış \%25.18 ile \%4 biochar dozunda görülmüştür (Çizelge 4). Kadmiyumun $10 \mathrm{mg} \mathrm{kg}^{-1}$ dozunun \%0 biochar uygulamasinda \%0.29 olan $\mathrm{P}$ konsantrasyonu $\% 2$ ve \%3 biochar dozunda $\% 0.34$ 'e, \%4 biochar dozunda ise \%0.36'ya çıkmıștır (Çizelge 4). Bu sonuçlara bakıldığında, toprağa biochar eklenmesiyle birlikte P'un adsorpsiyonu engellenerek bitkinin daha fazla P alması sağlandığı söylenebilir. Daha önce yapılan çalışmalarda da araştırıcılar, toprağa doğal organik madde eklenmesinin P'un fiksasyonunu azaltmak vasitasıyla P'un çözünürlüğünü arttırdığını ve böylece biochardaki anyonik moleküllerin P'un fosfat şeklinde fiksasyonunu engelleyerek doğal organik anyonlar olarak toprağın değişim komplekslerinde kaldıklarını ve bitkilerinde P'dan daha fazla yararlandıklarını rapor etmişlerdir (Bolan ve ark., 1994).

Çizelge 4. Farklı Cd ve Biochar dozları altında yetiştirilen ekmeklik buğdayın yeşil aksam P konsantrasyonları $(\%)$

\begin{tabular}{|c|c|c|c|c|c|c|}
\hline \multirow{2}{*}{ Biochar Dozu \% } & $\mathrm{Cd} 0$ & $\mathrm{Cd} 2.5$ & Cd5.0 & $\mathrm{Cd} 10$ & $\mathrm{Cd} 20$ & Ortalama \\
\hline & \multicolumn{6}{|c|}{ Yeşil aksam P konsantrasyonu (\%) } \\
\hline 0 & $0.29^{a}$ & 0.31 & $0.26^{\mathrm{a}}$ & $0.29^{a}$ & 0.29 & $0.29^{\mathrm{A}}$ \\
\hline 0,5 & $0.31^{\mathrm{a}}$ & 0.34 & $0.30^{\mathrm{ab}}$ & $0.33^{\mathrm{ab}}$ & 0.29 & $0.31^{\mathrm{A}}$ \\
\hline 1 & $0.39 \mathrm{~b}$ & 0.33 & $0.32^{\mathrm{bc}}$ & $0.32^{\mathrm{ab}}$ & 0.27 & $0.33^{\text {в }}$ \\
\hline 2 & $0.37^{b}$ & 0.36 & $0.32^{\mathrm{bc}}$ & $0.34^{\mathrm{b}}$ & 0.28 & $0.33^{\mathrm{B}}$ \\
\hline 3 & $0.37^{b}$ & 0.36 & $0.34^{\mathrm{cd}}$ & $0.34^{b}$ & 0.30 & $0.34^{\mathrm{B}}$ \\
\hline 4 & $0.38^{\mathrm{b}}$ & 0.35 & $0.37^{\mathrm{d}}$ & $0.36^{\mathrm{b}}$ & 0.29 & $0.35^{\mathrm{BC}}$ \\
\hline Ortalama & $0.35^{\mathrm{BC}}$ & $0.34^{\mathrm{B}}$ & $0.32^{\mathrm{B}}$ & $0.33^{\mathrm{B}}$ & $0.29^{A}$ & \\
\hline
\end{tabular}

*Sütunlarda aynı harfle gösterilen değerler arasında istatistiksel olarak $\mathrm{P}<0,05$ düzeyinde farklılık yoktur.

Çizelge 5. Farklı Cd ve Biochar dozları uygulanarak yetiştirilen ekmeklik buğdayın yeşil aksam K konsantrasyonları (\%)

\begin{tabular}{ccccccc}
\hline \multirow{2}{*}{ Biochar Dozu \% } & Cd0 & Cd 2.5 & Cd5.0 & Cd10 & Cd20 \\
\cline { 2 - 6 } & & \multicolumn{4}{c}{ Ortalama } \\
\hline 0 & $1.86^{\mathrm{a}}$ & 2.15 & 2.35 & 2.72 & 2.47 \\
0,5 & $1.86^{\mathrm{a}}$ & 2.16 & 1.99 & 2.54 & 2.23 & $2.31^{\mathrm{B}}$ \\
1 & $2.11^{\mathrm{abc}}$ & 2.21 & 2.45 & 2.53 & 2.55 & $2.36^{\mathrm{A}}$ \\
2 & $2.13^{\mathrm{bc}}$ & 2.20 & 2.51 & 2.27 & $2.37^{\mathrm{B}}$ & 2.54 \\
3 & $1.88^{\mathrm{ab}}$ & 2.47 & 2.44 & 2.35 & $2.34^{\mathrm{B}}$ \\
4 & $2.33^{\mathrm{c}}$ & 2.19 & 2.62 & 2.25 & $2.35^{\mathrm{B}}$ \\
\hline Ortalama & $2.03^{\mathrm{A}}$ & $2.23^{\mathrm{B}}$ & $2.39^{\mathrm{B}}$ & $2.44^{\mathrm{B}}$ & $2.44^{\mathrm{B}}$ \\
\hline
\end{tabular}

*Sütunlarda aynı harfle gösterilen değerler arasında istatistiksel olarak $\mathrm{P}<0,05$ düzeyinde farklılık yoktur.

Makro besin elementleri içerisinde biochar uygulamalarına göre istatistiksel olarak önemli düzeyde değişkenlik gösteren bir diğer element potasyumdur (K). Kadmiyum uygulaması yapılmayan koşullarda $\mathrm{K}$ konsantrasyonu \%1.86 (kontrol) ile \%2.33 (\%4 biochar) arasında değişkenlik göstermiştir. DUNCAN homojenlik testi sonuçlarına göre biochar \%4 uygulaması diğer uygulamaların tamamindan farklı olup kontrol uygulamasına göre yeşil aksamdaki $\mathrm{K}$ konsantrasyonu \% 25.19 oranında artış göstermiştir (Çizelge 5). Nigussie ve ark. (2012) marul bitkisine üç farklı dozda $\left(0,5\right.$ ve $\left.10 \mathrm{tha}^{-1}\right)$ biochar uygulaması ile bitkinin yeșil aksam K konsantrasyonunun 54.29 $\mathrm{g} \mathrm{kg}^{-1}$ 'dan $5 \mathrm{t} \mathrm{ha}^{-1}$ biochar dozunda 58.23, $10 \mathrm{t} \mathrm{ha}^{-1^{\prime}} \mathrm{da}$ ise $6.91 \mathrm{~g} \mathrm{~kg}^{-1}$ 'a çıktığını bildirmiştir. Araştırıcılar $\mathrm{K}$ konsantrasyonunda meydana gelen bu artışın biochar materyalinin kül kısmında bol miktarda bulunan yarayışlı $\mathrm{K}$ konsantrasyonundan kaynaklandığını bildirmişlerdir.

Toprağa artan dozlarda Cd uygulamasının tüm biochar uygulanan bitkilerin yeşil aksam $\mathrm{K}$ konsantrasyonlarında önemsiz de olsa artışa neden olduğu görülmüștür. Örneğin $\% 3$ biochar uygulamasının Cd0 dozunda \%1.88 olan yeşil aksam K konsantrasyonu $\mathrm{Cd}_{2.5}, \mathrm{Cd}_{5}, \mathrm{Cd}_{10}$ ve $\mathrm{Cd}_{20}$ dozlarında ise sırası ile $\% 2.47, \% 2.44, \% 2.35$ ve $\% 2.54$ şeklinde bir artış göstermiştir (Çizelge 5). 
Artan dozlarda biochar ve Cd uygulamalarının ekmeklik buğdayın yeşil aksam Fe ve Zn konsantrasyonları üzerine etkisi

Farklı dozlarda biochar uygulamaları ile ekmeklik buğday bitkisinin yeşil aksam demir (Fe) ve çinko
(Zn) konsantrasyonları istatistiksel olarak $(\mathrm{P}<0,05)$ değişmiştir. Yeşil aksam Fe konsantrasyonu 38.93 mg $\mathrm{kg}^{-1}$ ile $60.09 \mathrm{mg} \mathrm{kg}^{-1}$ arasinda, $\mathrm{Zn}$ konsantrasyonu $26.86 \mathrm{mg} \mathrm{kg}^{-1}$ ile $45.71 \mathrm{mg} \mathrm{kg}^{-1}$ arasında değişkenlik göstermiștir (Çizelge 6, 7).

Çizelge 6. Farklı Cd ve Biochar dozları uygulanarak yetiştirilen ekmeklik buğdayın yeşil aksam Fe konsantrasyonları $\left(\mathrm{mg} \mathrm{kg}^{-1}\right)$

\begin{tabular}{|c|c|c|c|c|c|c|}
\hline \multirow{2}{*}{ Biochar Dozu \% } & $\mathrm{Cd} 0$ & $\mathrm{Cd} 2.5$ & Cd5.0 & Cd10 & $\mathrm{Cd} 20$ & Ortalama \\
\hline & \multicolumn{6}{|c|}{ Yeşil aksam Fe konsantrasyonu (mg kg-1) } \\
\hline 0 & $40.78^{\mathrm{b}}$ & $67.01^{\mathrm{c}}$ & $42.92^{\mathrm{a}}$ & 48.83 & 53.23 & $42.13^{\mathrm{AB}}$ \\
\hline 0,5 & $47.40^{\mathrm{b}}$ & $52.55^{\mathrm{b}}$ & $47.71^{\mathrm{ab}}$ & 47.65 & 54.19 & $41.67^{\mathrm{AB}}$ \\
\hline 1 & $60.09^{a}$ & $53.24^{\mathrm{b}}$ & $54.90^{\mathrm{b}}$ & 44.65 & 52.10 & $44.33^{\mathrm{B}}$ \\
\hline 2 & $49.33^{\mathrm{ab}}$ & $50.46^{\mathrm{ab}}$ & $47.89^{\mathrm{ab}}$ & 57.19 & 53.02 & $43.32^{\mathrm{B}}$ \\
\hline 3 & $46.36^{\mathrm{b}}$ & $38.96^{\mathrm{a}}$ & $45.80^{\mathrm{a}}$ & 48.24 & 56.27 & $39.77^{A}$ \\
\hline 4 & $38.93^{\mathrm{b}}$ & $45.87^{\mathrm{ab}}$ & $39.77^{a}$ & 49.50 & 45.86 & $37.32^{\mathrm{A}}$ \\
\hline Ortalama & $47.15^{\mathrm{A}}$ & $51.35^{\mathrm{B}}$ & $46.50^{\mathrm{A}}$ & $49.34^{\mathrm{AB}}$ & $52.45^{\mathrm{B}}$ & \\
\hline
\end{tabular}

*Sütunlarda aynı harfle gösterilen değerler arasında istatistiksel olarak $\mathrm{P}<0,05$ düzeyinde farklılık yoktur.

Toprağa 5 mg kg-1 dozunda Cd uygulaması altında ekmeklik buğday bitkisinin yeşil aksam $\mathrm{Fe}$ konsantrasyonu, kontrol uygulamasina göre biocharın \%0.5 ve \%1 dozlarında artış meydana gelmiş, ancak biocharın $\% 2, \% 3$ ve $\% 4$ dozunda ise Fe konsantrasyonlarında azalış meydana gelmiștir (Çizelge 6). Toprağa $5 \mathrm{mg} \mathrm{kg}^{-1}$ dozunda $\mathrm{Cd}$ uygulaması altında biochar uygulama dozları arasında istatistiksel olarak önemli düzeyde değișkenlik gösteren Zn konsantrasyonu 43.97 mg $\mathrm{kg}^{-1}$ (kontrol) ile $70.40 \mathrm{mg} \mathrm{kg}^{-1}$ (\%4 biochar) arasında değișkenlik göstermiștir. Çinko konsantrasyonu biochar dozlarının artmasına paralel olarak artış gösterirken, en yüksek artış biocharın 4 dozunda (\%60.10) elde edilmiștir. (Çizelge 7). Artan biochar uygulamaları altında Cd'un $10 \mathrm{mg} \mathrm{kg}^{-1}$ dozunda kontrol uygulamasına göre Fe ve Zn konsantrasyonlarında en yüksek artış (\%17.12) $\% 2$ biochar dozunda $\mathrm{Fe}$ konsantrasyonunda görülmüștür. Her ne kadar kontrol uygulamasına göre yüksek oranda değişim olsa da bu değişim istatistiksel olarak önemli $(\mathrm{P}<0,05)$ düzeyde çıkmamıştır. Biochar uygulama dozlarının artmasıyla beraber $\mathrm{Fe}$ ve $\mathrm{Zn}$ konsantrasyonları kontrol uygulamasına oranla neredeyse tüm uygulama dozlarında bir azalış göstermiştir (Çizelge 6 ve 7).

Çizelge 7. Farklı Cd ve Biochar dozları altında yetiştirilen ekmeklik buğdayın yeşil aksam Zn konsantrasyonları (mg kg-1)

\begin{tabular}{|c|c|c|c|c|c|c|}
\hline \multirow{2}{*}{ Biochar Dozu \% } & $\mathrm{Cd} 0$ & $\mathrm{Cd} 2.5$ & Cd5.0 & $\mathrm{Cd} 10$ & $\mathrm{Cd} 20$ & Ortalama \\
\hline & \multicolumn{6}{|c|}{ Yeșil aksam Zn konsantrasyonu (mg kg-1) } \\
\hline 0 & $26.86^{\mathrm{a}}$ & 54.84 & $43.97^{a}$ & 51.87 & 55.09 & $46.53^{\mathrm{A}}$ \\
\hline 0,5 & $30.72^{\mathrm{a}}$ & 43.56 & $47.46^{\mathrm{a}}$ & 50.46 & 49.39 & $44.32^{\mathrm{A}}$ \\
\hline 1 & $44.42^{\mathrm{b}}$ & 46.64 & $50.49^{a}$ & 47.06 & 47.98 & $47.32^{\mathrm{A}}$ \\
\hline 2 & $40.09^{b}$ & 48.37 & $64.40^{\mathrm{b}}$ & 51.46 & 51.93 & $51.25^{\mathrm{B}}$ \\
\hline 3 & $38.07^{b}$ & 64.99 & $65.20^{\mathrm{b}}$ & 52.53 & 50.65 & $54.29^{\mathrm{B}}$ \\
\hline 4 & $45.71^{\mathrm{b}}$ & 50.06 & $70.40^{\mathrm{b}}$ & 48.32 & 43.14 & $51.53^{\text {в }}$ \\
\hline Ortalama & $37.65^{A}$ & $51.41^{\mathrm{B}}$ & $56.99^{C}$ & $50.28^{\mathrm{B}}$ & $49.70^{\mathrm{B}}$ & \\
\hline
\end{tabular}

*Sütunlarda aynı harfle gösterilen değerler arasında istatistiksel olarak $\mathrm{P}<0,05$ düzeyinde farklılık yoktur.

Al Wabel ve ark. (2014) misır bitkisine 4 farklı dozda $\left(0,1,3\right.$ ve $\left.5 \mathrm{~g} \mathrm{~kg}^{-1}\right)$ biochar uygulaması yaptıkları bir çalışmada, mısır bitkisinin yeşil aksam Fe konsantrasyonunun kontrol uygulamasinda $624 \mathrm{mg}$ $\mathrm{kg}^{-1}$ iken biocharın $1 \mathrm{~g} \mathrm{~kg}^{-1}$ dozunda $890 \mathrm{mg} \mathrm{kg}^{-1}, 3 \mathrm{~g}$ $\mathrm{kg}^{-1}$ dozunda $957 \mathrm{mg} \mathrm{kg}^{-1}$ ve $5 \mathrm{~g} \mathrm{~kg}^{-1}$ dozunda ise $757 \mathrm{mg} \mathrm{kg}-1$ olduğunu bildirmişlerdir. Yapılan bir sera çalışmasında iki farklı tütün (Nail ve Xanti/2A) çeşidine topraktan 4 farklı dozda Cd $(0,0.25,2.5$ ve $10 \mathrm{mg} \mathrm{kg}^{-1} \mathrm{Cd}$ ) uygulaması yapılmış ve toprağa artan düzeyde uyguladıkları Cd'un tütün bitkisinin yeşil aksam Fe konsantrasyonunun Nail çeşidinde Cd'un 0 mg kg-1 dozunda $203.3 \mathrm{mg} \mathrm{kg}^{-1}$ iken $0.25 \mathrm{mg} \mathrm{kg}^{-1}$ dozunda $167.1 \mathrm{mg} \mathrm{kg}^{-1}, 2.5 \mathrm{mg} \mathrm{kg}^{-1}$ dozunda 212.4 $\mathrm{mg} \mathrm{kg}^{-1}$ ve $10 \mathrm{mg} \mathrm{kg}^{-1}$ dozunda ise $140.7 \mathrm{mg} \mathrm{kg}^{-1}$ olduğu bildirilmiştir. Aynı çalışmada, Xanthi/2A 
çeşidinde ise toprağa yapılan $\mathrm{Cd}$ uygulama dozu arttıkça bitkinin yeşil aksam Fe konsantrasyonunda önemli azalmaların olduğu bildirilmiştir (Erdem ve ark., 2012). Zheng ve ark. (2013) Cd toksititesi olan bir toprağa iki farklı dozda biochar (\% 0 ve \% 5) uygulamasının buğday bitkisinin $\mathrm{Zn}$ alımını istatiksel açıdan $(\mathrm{p}<0.05)$ önemli düzeyde azalttığını bildirmişlerdir.

\section{Sonuç}

Sonuçlar, Ceyhan-99 ekmeklik buğday bitkisinin yeşil aksam kuru madde verimi üzerine biochar uygulamalarının etkisi sadece $\mathrm{Cd} 0 \mathrm{mg} \mathrm{kg}^{-1}$ dozunda istatistiksel olarak önemli çlkarken, toprağa artan düzeyde biochar uygulanması ile kuru madde verimi kontrol uygulamalarına göre istatistiksel olarak azalmıştır. Ayrıca, her bir biochar dozunda toprağa uygulanan Cd dozunun artması ile yeşil aksam kuru madde verimi azalmıştır. $\mathrm{Bu}$ azalışın, Cd'un fotosentez enzimlerinin işlevselliğini azaltmasından kaynaklandığ 1 düşünülmektedir. Kadmiyum uygulamasının yapılmadığı koşullarda N, P, K, Fe ve Zn konsantrasyolarında biochar uygulama dozlarına bağlı olarak meydana gelen değişkenlik istatistiksel olarak önemli çıkmıștır. Biochar uygulama dozlarına bağlı olarak besin elementi konsantrasyonları kontrol uygulamalarına göre artış göstermiştir. Bu artışın temel nedeninin, biochar uygulama dozlarına bağlı olarak besin elementlerinin toprak çözeltisindeki çözünürlüklerinin artmasından kaynaklandığı düşünülmektedir. Kadmiyum uygulama dozlarının artması $\left(2.5,5,10,20 \mathrm{mg} \mathrm{kg}^{-1}\right)$ neticesinde biochar materyalinin uygulanma oranları arasında meydana gelen değişim istatistiksel olarak önemli çıkmıştır. Özellikle Cd 10 ve $20 \mathrm{mg} \mathrm{kg}^{-1}$ dozunda biochar uygulama dozlarının artması ile yeşil aksam Cd konsantrasyonu önemli düzeyde azalış göstermiştir. Kadmiyumun $10 \mathrm{mg} \mathrm{kg}^{-1}$ dozu uygulaması altında kontrol koşullarına göre $\% 4$ biochar materyalinin uygulandığı bitkilerde yeşil aksam Cd konsantrasyonu \%40,49 oranında azalış göstermiştir. Kadmiyumun $20 \mathrm{mg} \mathrm{kg}{ }^{-1}$ dozu uygulaması altında ise, kontrol uygulamasına göre $\% 4$ biochar uygulamasında yeşil aksam Cd konsantrasyonu \%35,76 oranında azalış göstermiştir. Meydana gelen bu azalışın temel nedeni, oldukça yüksek adsorbe yeteneğine sahip olan biochar materyalinin negatif yüzeylerinde $\mathrm{Cd}^{++}$ iyonlarının değişim yüzeylerinde sıkı bağlanması ve toprak çözeltisi içerisindeki konsantrasyonunun azalmasından kaynaklanmaktadır. Sonuç olarak, ağır metal kirliliğine maruz kalmış arazilerde ıslah materyali olarak biocharın rahatlıkla kullanılabileceği kanıtı olmuştur.

\section{Kaynaklar}

Al-Wabel, M., Usman, A.R.A., El-Naggar, A.H., Aly, A.A., Ibrahim, H.M., Elmaghraby, S. \& Al-Omran, A., (2014). Conocarpus biochar as a soil amendment for reducing heavy metal availability and uptake by maize plants. Saudi Journal of Biological Sciences. 22(4), 503-511.

Alloway, B. J. (2012). Heavy metals in soils: trace metals and metalloids in soils and their bioavailability (Vol. 22). Springer Science \& Business Media.

Asri, F.Ö. \& Sönmez, S. (2006). Ağır Metal Toksisitesinin Bitki Metabolizması Üzerine Etkileri. Derim, Batı Akdeniz Tarımsal Enstitüsü Dergisi, 23(2), 36-45.

Asri, F. Ö., Sönmez, S., \& Çitak, S. (2007). Kadmiyumun Çevre ve İnsan Sağlı̆̆ Üzerine Etkileri. Derim, 24(1), 32-39.

Bolan, N., Naidu, S., Mahimairaja, R., \& Baskaran, S. (1994). Influence of low-molecular-weight organic acid on the solubilization of phosphates. Biology and Fertility of Soils, 18, 311-319.

Bremner, J.M. (1965). Total nitrogen. In C.A.Black et al. (ed.) Methods of soil analysis. Am. Soc. of Agron., Inc.Madison, Wisconsin, USA, Part 2. Agron. 9, 11491178.

Chen, W.F., Zhang, W.M., Meng, J., \& Xu, Z.J. (2011). Researches on biochar application technology. Engineering Sciences, 13, 83-89.

Erdem, H., Kınay, A., Oztürk, M., \& Tutus, Y., (2012). Effect of cadmium stress on growth and mineral composition of two tobacco cultivars. Journal of Food, Agriculture \& Environment, 10(1), 965-969.

Goyer, R.A., Miller C.R., Zhu S.Y., \& Victery W. (1989). Nonmetallothionein bound cadmium in the pathogenesis of cadmium nephropathy in the rat. Toxicology and Applied Pharmacology, 101, 232244.

Gussarson, M., Asp, H., Adalststeinsson, S., \& Jensen, P. (1996). Enhancement of cadmium effects on growth and nutrient composition of birch (Betula pendula) by buthionine sulfoximine (BSO). Journal of Experimental Botany, 47, 211-215. 
Gür, N., Topdemir, A., Munzuroğlu, Ö., \& Çobanoğlu, D. (2004). Ağır Metal İyonlarının $(\mathrm{Cu}+2, \mathrm{~Pb}+2, \mathrm{Hg}+2$, $\mathrm{Cd}+2)$ Clivia sp. Bitkisi Polenlerinin Çimlenmesi ve Tüp Büyümesi Üzerine Etkileri. F.Ü. Fen ve Matematik Bilimleri Dergisi, 16(2), 177-182.

Haktanır, K. (1987). Çevre Kirliliği. A.Ü. Ziraat Fakültesi Ders Notu, Teksir No: 140

Hernandez, L.E., Ramos, I., Carpena-Ruiz, R.,Lucena, J.J., \& Garate, A. (1996). Effect ofcadmium on the distribution ofmicronutrients in Lactuca spp., maize andpea plants. In: Fertilizers and Environment,ed, C. Rodriguez-Barrueco, KluwerAcademic Publishers, 503-508.

Jarup, L., Berglund, M., Elinder, C. G., Nordberg, G., \& Vather, M. (1998). Health effects of cadmium exposurea review of the literature and risk estimate. Scandinavian Journal of World Environmental Health, 24, 1- 52.

Kacar, B., \& İnal, A. (2008). Bitki Analizleri. Nobel Yayınları, Ankara.

Kalınbacak, K., Yurdakul, İ., \& Gedikoğlu, İ. (2012). Buğdayda Kadmiyumun Toksiklik Sinırının Belirlenmesi ve BazıEkstraksiyon Yöntemlerinin Karşılaștırılması. Toprak Su Dergisi, 1(1), 28-37

Khurana, M.P.S., \& Jhanji, S. (2014). Influence of cadmium on dry matter yield, micronutrient content and its uptake in some crops. Journal of Environmental Biology, 35(5), 865.

Kramer, R.W., Kujawinski, E.B., \& Hatcher, P.G. (2004). Identification of black carbon derived structures in a volcanic ash soil humicacid by Fourier transform ion cyclotron resonance mass spectrometry. Environmental Science ve Technology, 38, 3873395.

Lehmann, J., Rillig, M.C., Thies, J., Masiello, C.A., Hockaday, W.C., \& Crowley, D. (2011). Biochar effects on soil biota-a review. Soil Biology and Biochemistry, 43(9), 1812-1836.

Lu, H., Zhang, Y.Y., Huang, X., Wang, S., \& Qiu, R. (2012). Relative distributionof $\mathrm{Pb} 2+$ sorption mechanisms by sludge-derived biochar. WatRes, 46, 854-862

Major, J., Rondon, M., Molina, D., Riha, S.J., \& Lehmann, J. (2012). Nutrient leaching in a Colombian savanna Oxisol amended with biochar. Journal of environmental quality, 41(4), 1076-1086.
Namgay, T., Singh, B., \& Singh, B.P. (2010). Influence of biochar application to soil on the availability of As, $\mathrm{Cd}, \mathrm{Cu}, \mathrm{Pb}$, and $\mathrm{Zn}$ to maize (Zea mays L.). Soil Research, 48(7), 638-647.

Nigussie, A., Kissi, E., Misganaw, M., \& Ambaw, G. (2012). Effect of Biochar Application on Soil Properties and Nutrient Uptake of Lettuces (Lactuca sativa) Grown in Chromium Polluted Soils. American-Eurasian Journal of Agricultural and Environmental Sciences, 12(3), 369-376.

Pena, J.M., Allen, N.S., \& Edge, M. (2000). Analysis of radical content on carbon black pigments by electron spinresonance: Influence of functionality, thermal treatment and adsorption of acidic and basic probes. Polymer Degradation and Stability, 71, 153170.

Pereira, B.F.F., Rozane, D.E., Araújo, S.R., Barth, G., Queiroz, R.J.B., Nogueira, T.A.R., \& Malavolta, E. (2011). Cadmium availability and accumulation by lettuce and rice. Revista Brasileira de Ciência do Solo, 35(2), 645-654.

Rengel, Z. (2003). Handbook of soil acidity (Vol. 94). CRC Press.

Sheoran, I.S., Singal, H.R., \& Singh, R. (1990). Effect of cadmium and nickel on photosynthesis and enzymes of the photosynthetic carbon reduction cycle in pigeon pea (Cajanus cajan L.). Photosynthesis Research, 23, 345-351.

Van A., \& Clijsters, H. (1990). Effect of metalson enzyme activity in plants. Plant Cell Environment, 13, 195206.

Washington, J.B., \& Joseph J.P. (2003). Sorption hystersis of ben-zene in charcoal particles. Environmental Science ve Technology, 37, 409-417.

Yang, X., Baligar, V.C., Martens, D.C., \& Clark, R.B. (1996). Cadmium effects on influx and transport of mineral nutrients in plant species. Journal of Plant Nutrition, 19, 643-656.

Yıldız, N. (2001). Toprak Kirletici Bazı Ağır Metallerin (Zn, $\mathrm{Cu}, \mathrm{Cd}, \mathrm{Pb}, \mathrm{Co}$ ve $\mathrm{Ni}$ ) Belirlenmesinde Kullanılan Yöntemler. Atatürk Üniversitesi Ziraat Fakültesi Dergisi, 32(2), 207-213.

Zhang, A.F,. Pang, X., \& Li, L.Q. (2009). Biochar and the effect on c stock enhancement, emission reduction of greenhouse gases and soil reclamation. Journal of Agro-Environment Science, 28, 2459-2463. 
Zheng, R., Chen, Z., Cai, C., Wang, X., Huang, Y., Xiao, B., \& Sun, G., (2013). Effect of biochars from rice husk, bran and straw on heavy metal uptake by pot grown wheat seedling in a historically contaminated soil. BioResources, 8(4), 5965-5982. 